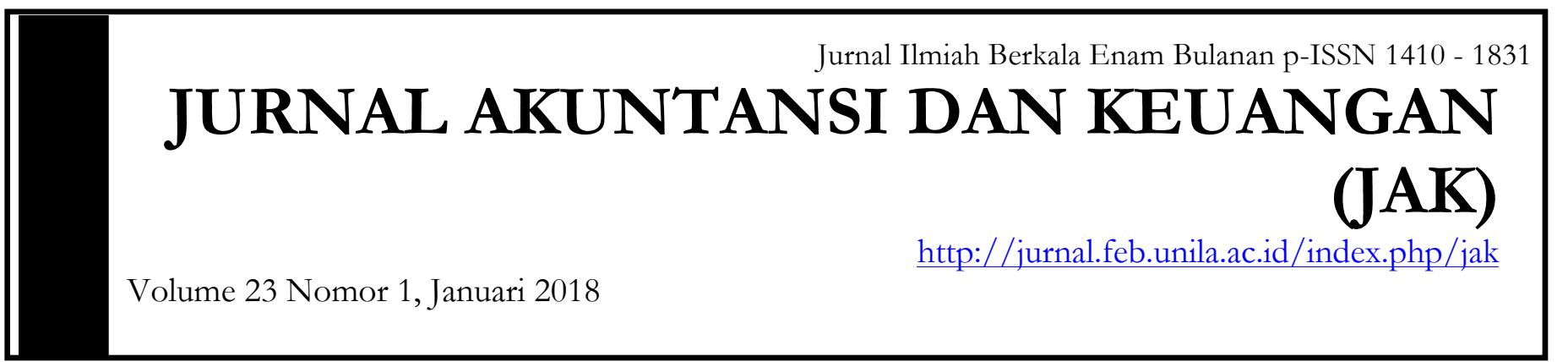

\title{
ANALISIS CAPAIAN KINERJA PELAKSANAAN ANGGARAN PENERAPAN APLIKASI ELECTRONIC MONITORING PELAKSANAAN ANGGARAN (e- MPA)
}

\author{
Atikah Rosalinda ${ }^{1}$, Rindu Rika Gamayuni ${ }^{2}$ \\ ${ }^{1}$ Program Studi Akuntansi FEB Universitas Lampung \\ ${ }^{2}$ Program Studi Akuntansi FEB Universitas Lampung
}

\section{Informasi Naskah}

Update Naskah:

Dikumpulkan: 19 Sept 2017;

Diterima: 22 January 2018;

Terbit/Dicetak: 30 January 2018.

\section{Keywords:}

Budget Absorption Consistancy, Budget Absorption Realization, Budget Execution Performance Achievement, Budget Execution Electronic Monitoring (e-MPA), Technology Task of Fit.

\begin{abstract}
This study aim to examine and found the empirical evidence the consistancy between budget absorption and realization after the implementation of Electronic Monitoring Budget Execution aplication (e-MPA) at Ministry of Religion working unit at Lampung Province. This study use 4.416 population data for the period of 2012 until 2013 before the implementation of e-MPA aplication and the period of 2015 until 2016 after the implementation of e-MPA aplication. Data used are secondary data obtained by accessing the site http://www.kemenag.go.id. The data analyzed using differentiation test with statistical test tool SPSS 22. The result shows that there is a difference of consistancy of budget absorption and there is also a difference on budget realization after the implementation of e-MPA aplication.the difference occured is the decreasing on statistic result of absorption consistancy and absorption realization for budgeting that indicates there is no goal congruence caused by communication pattern, information support, and uncorrect guidelines comprehension for e-MPA aplication.
\end{abstract}




\section{A. PENDAhuluan}

Kondisi penyerapan anggaran Kementerian/Lembaga hingga akhir Agustus 2011 adalah sebesar Rp185,91triliun dari total Pagu DIPAK/L (Rp. 436triliun) atau sebesar 43\%. Sementara itu, bila dilihat menurut jenis belanja, dari keempat jenis belanja, yakni belanja pegawai, belanja barang, belanja modal, dan bantuan, hanya belanja pegawai yang memiliki penyerapan anggaran yang cukup tinggi yakni $75 \%$ sedangkan belanja lainnya masih dibawah 50\%, yakni belanja barang $37 \%$, belanja modal 28\%, bantuan sosial 40\%. Sampai akhir Desember 2011 kondisi penyerapan anggaran Kementerian/ Lembaga sebesar Rp. 473,36 triliun dari total pagu DIPA K/L sebesar Rp. 548,46 triliun atau sebesar $86,31 \%$. Bila dilihat menurut jenis belanja maka belanja pegawai memiliki penyerapan anggaran yang paling besar yakni 95,99\%, sedangkan belanja lainnya, yakni belanja barang 79,33\%, belanja modal $80,63 \%$, bantuan sosial $86,64 \%$. Berdasarkan data-data tersebut, maka perlu perbaikan dalam kinerja pelaksanaan anggaran, oleh karena itu sejumlah Kementerian/Lembaga berupaya melakukan perbaikan dalam penyerapan anggaran. Menurut Sekretaris Jenderal Kementerian Agama (Kemenag) RI (Media Indonesia, 2012) dalam Rapat Koordinasi Pengelolaan Anggaran Kemenag pada tahun 2012, menyebutkan bahwa rencana dan realisasi pelaksanaan anggaran di Kemenag masih perlu diperbaiki terutama pada pola penyerapan anggaran yang sering dilakukan pada akhir masa anggaran. Sekretaris Jenderal Kemenag RI menambahkan, secara umum pola kinerja pelaksanaan anggaran tersebut selalu lambat pada triwulan I sampai triwulan III. Optimalisasi anggaran tersebut lebih banyak dikebut pada triwulan IV, sehingga tidak baik dan berpeluang tidak efektifnya anggaran (Media Indonesia, 2012).

Penelitian ini merupakan pengembangan dari penelitian sebelumnya yang dilakukan oleh Goodhue dan Thompson (1995), yaitu tentang kesesuaian antara kemampuan teknologi dengan tuntutan pekerjaan, suatu kemampuan teknologi untuk mendukung pekerjaan. Dishaw dan Strong (1999) menyebutkan bahwa teori task/technology fit menjelaskan kerangka yang merupakan faktor-faktor dan risiko-risiko yang berhubungan dengan implementasi teknologi informasi dalam organsasi yang dapat diidentifikasi.

Beberapa penelitian terdahulu di beberapa negara telah ditemukan praktik-praktik dalam pengguaan aplikasi electronic government dalam sistem pemerintahannya. Chang (2012) menyebutkan bahwa implementasi e-government di China berevolusi sesuai dengan kebutuhan perkembangan masa dengan perbedaan implementasi yang lebih mengarah pada transparansi dan pembatasan kekuasaan namun memperhatikan kekuatan hubungan horizontal dengan masyarakat. Stanimirovic dan Mirko (2013) mengatakan bahwa beberapa negara di Uni Eropa saat ini kurang dalam hal regulasi dan belum memiliki metodologi yang tepat dalam mengevaluasi kebijakan e-government sehingga dalam jangka panjang masih minim kualitas konsep, perencanaan, dan implementasi kebijakan e-government. Kareem dan Haseeni (2015) menemukan bahwa aplikasi e-government mampu meningkatkan kinerja organisasi. Temuan penting dalam risetnya adalah di Najaf, India, belum terdapat banyak dukungan regulasi yang mendukung e-government.

Imran (2011) mengatakan aplikasi sistem monitoring penyerapan anggaran berbasis website dapat untuk mengevaluasi permasalahan penyerapan anggaran, antara lain informasi yang dihasilkan adalah kinerja bendaharawan kegiatan dalam melakukan penggunaan anggaran, evaluasi pengeluaran dengan target realisasi anggaran. Sejalan dengan penelitian Kurniadi (2015) Sistem Informasi yang dikembangkan berbasis web ini dapat membantu dalam membuat dan menyusun rencana kerja dan anggaran, serta memberikan informasi rencana kerja dan anggaran secara langsung dan jelas pada pihak terkait sehingga kegiatan penyusunan dan monitoring lebih mudah dan bisa dilakukan diberbagai tempat.

Penelitian ini bertujuan utuk mengetahui perbedaan capaian kinerja pelaksanaan anggaran sebelum dan sesudah penggunaan aplikasi e-MPA. mendeskripsikan secara obyektif capaian kinerja pelaksanaan anggaran pasca implementasi aplikasi e-MPA pada satker Kementerian Agama di seluruh provinsi Lampung, dengan harapan dapat memberikan bukti dan gambaran yang lebih nyata mengenai keberhasilan e-MPA dalam capaian kinerja pelaksanaan anggaran. 


\section{B. LANDASAN TEORI DAN PENGEMBANGAN HIPOTESIS Konsistensi Realisasi Serapan Anggaran}

Merujuk pada publicinterest theory bahwa regulasi diciptakan agar dapat memaksimalkan kesejahteraan sosial. Dalam hal ini, kesejahteraan sosial direpresentasikan dengan adanya kemampuan lembaga negara dalam pelayanan masyarakat dibuktikan dengan kinerja yang baik. Kinerja yang baik tersebut diukur dengan regulasi tertentu sebagai standar dalam penilaian suatu lembaga dalam pelayanan kepada masyarakat. Berdasarkan teori agensi, lembaga negara merupakan agen yang wajib melaporkan kinerjanya kepada masyarakat sebagai prinsiple. Salah satu regulasi dalam kaitannya dengan kedua teori tersebut adalah. Peraturan Menteri Keuangan No. 249 Tahun 2011. PMK No.249 Tahun 2011 tersebut menyebutkan bahwa kinerja pada aspek implementasi merupakan aspek evaluasi kinerja atas pelaksanaan RKA-KL tahun sebelumnya dan tahun berjalan yang dilakukan dalam rangka menghasilkan informasi kinerja mengenai pelaksanaan kegiatan dan pencapaian keluaran, indikator yang diukur salah satunya adalah konsistensi antara perencanaan dan implementasi. Dengan demikian, salah satu pengukuran dan evaluasi kinerja sesuai PMK No. 249 Tahun 2011 adalah dengan menempatkan konsistensi antara perencanaan dan implementasi sebagai salah satu indikator keberhasilan kinerja. Konsistensi yang dimaksud tercantum pada aplikasi e-MPA berisi tentang data perencanaan target penyerapan anggaran selama satu tahun dan realisasi pelaksanaan anggaran yang dilaporkan secara berkala setiap bulannya. Dalam PMK 249 Tahun 2011 disebutkan bahwa nilai konsistensi seharusnya sesuai antara perencanaan dan target anggaran yang artinya tidak kurang atau tidak lebih dari target tersebut. Dengan demikian, apabila realisasi anggaran melebihi anggaran yang ditetapkan maka dianggap tidak konsisten. Aplikasi e-MPA bertujuan untuk meningkatkan capaian kinerja Kemenag. Asumsinya, dengan adanya dukungan e-MPA, konsistensi yang dihasilkan oleh lembaga negara ini semakin baik. Sugiarto dan Mutiari (2016) mengatakan konsistensi terjadi adanya relasi kepentingan antar semua aktor dari proses perencanaan sampai penganggaran dengan mempunyai tujuan yang sama dalam mencapai visi misi daerah. Sedangkan Gea (2006) mengartikan konsisten sebagai kesesuaian antara perkataan dan tindakan. Berdasarkan teori dan beberapa penelitian sebelumnya tentang konsistensi antara perencanaan dan implementasi, dapat disusun hipotesis sebagai berikut.

$\mathrm{H}_{1}$ : Terdapat beda konsistensi realisasi serapan anggaran sebelum dan setelah penerapan e-MPA

\section{Penyerapan Anggaran}

Berdasarkan public intetest theory, anggaran yang diserap dan digunakan untuk membiayai program untuk masyarakat adalah sebagai bentuk ketercapaian kinerja yang baik (Mardiasmo, 2002). Dengan demikian, penyerapan anggaran dengan dukungan sistem berupa aplikasi e-MPA yang dapat digunakan untuk pengawasan ketercapaian anggaran. Hal ini akan mendorong peningkatan kinerja dalam bentuk realisasi program untuk kesejahteraan masyarakat. Penelitian terdahulu berkaitan dengan anggaran yaitu penelitian Locke (1968) dalam Kenis (1979) menunjukkan hubungan kejelasan sasaran anggaran berpengaruh signifikan dengan kinerja manajerial. Hal ini didukung oleh penelitian yang dilakukan Kennis (1979) pengaruh partisipasi anggaran dan kejelasan anggaran cenderung memiliki pengaruh positif dan signifikan terhadap sikap dan kinerja anggaran para manajer. Selanjutnya hasil penelitian Kenis (1979) diperkuat (Pasoloran, 2002) bahwa variasi dalam karakteristik penganggaran memiliki pengaruh yang signifikan pada kinerja manajerial.Disisi lain berdasarkan teori task/technology fit, kinerja manajerial dalam hal ini adalah serapan anggaran dengan laporan berbasis teknologi ditentukan oleh beberapa hal. Chua dan Lam (2005) menyebutkan adanya manajemen mengalami kegagalan dalam penggunaan teknologi adalah akibat kurang tepatnya sistem teknologi yang digunakan dengan manajemen organisasi. Selain itu, Turner, et al. (2008) juga menyebutkan adanya perbedaan antara desain teknologi dan faktor lingkungan pengguna teknologi yang menyebabkan perbedaan hasil dari penggunaan teknologi. Berdasarkan beberapa penelitian sebelumnya tentang realisasi penyerapan anggaran dengan dukungan sistem berupa aplikasi e-MPA, dapat dikembangkan hipotesis kedua sebagai berikut: 
$\mathrm{H}_{2}$ : Terdapat beda realisasi serapan anggaran sebelum dan sesudah penerapan aplikasi e-MPA.

\section{METODE PENELITIAN}

\section{Populasi dan Sampel}

Populasi dalam penelitian ini adalah seluruh satuan kerja (satker) dibawah naungan Kanwil Kementerian Agama. Provinsi Lampung. Dengan data observasi 4.416 data.

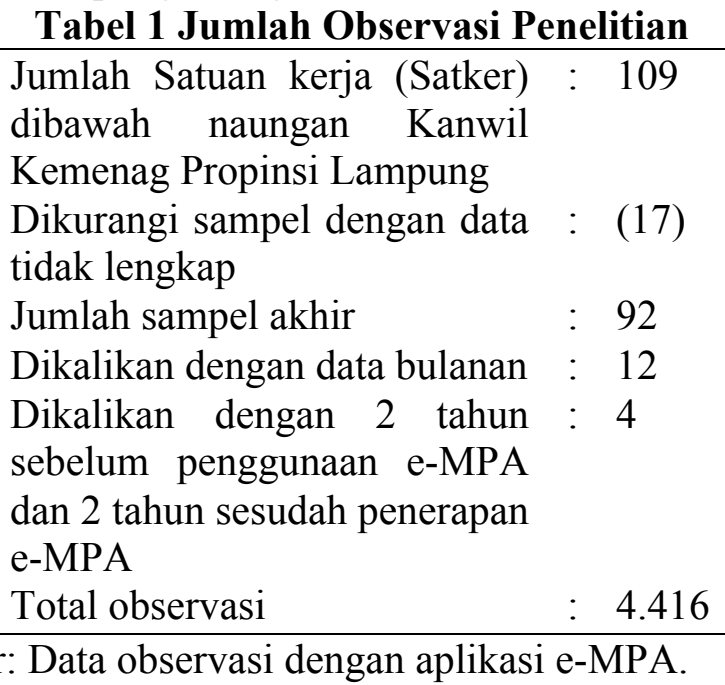

Data yang digunakan dalam penelitian ini adalah data sekunder dengan cara mengakses data dan mengobservasi data sekunder berupa laporan perencanaan dan penyerapan anggaran pada aplikasi eMPA satu persatu satker dibawah naungan Kantor Kementerian Agama Provinsi Lampung dengan mengamatisatu persatu aplikasi e-MPA satkerpada alamat situs http://e-mpa.kemenag.go.id

Variabel yang digunakan dalam penelitian ini adalah Capaian Kinerja Pelaksanaan Anggaran pada aplikasi e-MPA dengan lima indikator berupa pertama laporan pagu anggaran, kedua laporan komposisi anggaran menurut jenis belanja, ketiga laporan konsistensi serapan anggaran, keempat laporan realisasi serapan anggaran, kelima laporan capaian pelaksanaan kegiatan kunci. Namun hanya menggunakan 2 variabel yaitu laporan konsistensi serapan anggaran dan laporan realisasi serapan anggaran dikarenakan hanya kedua data tersebut yang tersedia lengkap pada aplikasi e-MPA

Pengukuran konsistensi realisasi serapan anggaran $(\mathrm{K})$ dilakukan untuk mengukur konsistensi ketepatan waktu pelaksanaan kegiatan yang direpresentasikan dengan ketepatan waktu penyerapan anggaran setiap bulan. Sementara Pengukuran realisasi penyerapan anggaran (P) digunakan untuk menilai seberapa besar anggaran yang telah digunakan untuk membiayai kegiatan. Pengukuran kedua variabel tersebut merujuk pada PMK No. 249 Tahun 2011 pada Pasal 11 sampai dengan Pasal 14 yang menjelaskan bahwa pengukuran adalah proses menghasilkan suatu nilai capaian kinerja untuk setiap indikator yang dilakukan dengan membandingkan data realisasi dengan target yang telah direncanakan sebelumnya.

Pengukuran konsistensi:

Keterangan :

$\mathrm{K}$ : Konsistensi

RA: Realisasi anggaran

RPD : Rencana penarikan anggaran

$\underline{k}=\frac{\sum_{i=1}^{i} \text { RA bulan ke j }}{\sum_{i=1}^{i} \text { RPD bulan ke j }}$

Pengukuran Realisasi Penyerapan Anggaran:

Keterangan : $\quad$ P: Penyerapan anggaran 
RA: Akumulasi realisasi anggaran satuan kerja

PA: Akumulasi pagu anggaran satuan kerja

$$
\rightarrow \quad P=\frac{\mathrm{RA}}{\mathrm{PA}} \mathrm{X} 100 \%
$$

Teknis analisis data dalam penelitian ini menggunakan uji beda rata-rata sampel berpasangan karena akan membandingkan rata-rata dari dua variabel. Dalam menganalisis data membutuhkan perangkat lunak yaitu SPSS versi 22.

Data yang ada merupakan data non parametik, maka dalam menguji data digunakan uji Wilcoxon yaitu dengan menguji data non parametik, artinya data tersebut tidak berdistribusi normal serta data bertipe interval atau ratio, maka uji Wilcoxon digunakan untuk menganalisis hasil-hasil pengamatan yang berpasangan dari dua data apakah berbeda atau tidak.

\section{ANALISIS DAN PEMBAHASAN}

\section{Hasil}

Tabel 1 Descriptive Statistics

\begin{tabular}{llllll}
\hline & $\mathrm{N}$ & Minimum & Maximum & Mean & Std. Deviation \\
\hline x1_before & & & &, 900833 & \\
& 2208,18045 & 3,58823 & 1 &, 18708114 \\
x1_after & & & & 1 & \\
& 2208,12045 & 2,42852 & 1 &, 23891307 \\
x2_before & & & &, 078724 & \\
& 2208,00206 &, 47510 & 0 &, 04342509 \\
x2_after & & & &, 074338 & \\
& 2208,00000 &, 50419 & 2 &, 03810840 \\
Valid & & & & & \\
(listwise) & 2208 & & & & \\
\hline
\end{tabular}

a. $\mathrm{x} 1=$ Konsistensi Penyerapan Anggaran

b. $\mathrm{x} 2=$ Realisasi Penyerapan Anggaran

Sumber: Output SPSS Versi 22.

Berdasarkan Tabel 4.1 statistik deskriptif tersebut diketahui bahwa nilai maksimum untuk variabel konsistensi penyerapan anggaran (X1) sebelum diterapkan penerapan aplikasi e-MPA adalah 3,588226. Dan untuk nilai minimum untuk variabel konsistensi penyerapan anggaran (X1) sebelum diterapkan penerapan aplikasi e-MPA adalah 0,1804469. Adapun nilai maksimum konsistensi penyerapan anggaran setelah aplikasi e-MPA yaitu 2,428521. Dan nilai konsistensi penyerapan anggaran terendah setelah penerapan aplikasi e-MPA adalah 0,120446. Pada nilai mean untuk variabel konsistensi terdapat penurunan sebesar 0,030623. Nilai maksimum sebelum diterapkan aplikasi eMPA untuk variabel x2 realisasi penyerapan anggaran 0,47510111. Dan untuk angka penyerapan anggaran terendah sebelum diterapkan aplikasi e-MPA dengan nilai 0,00205619. Sedangkan, setelah diterapkan aplikasi e-MPA nilai maksimum untuk penyerapan anggaran bernilai 0,504186. Dan posisi terendah dalam penyerapan anggaran setelah penerapan aplikasi e-MPA adalah dengan nilai 0,0000. Hal ini juga menunjukkan bahwa terdapat peningkatan pada nilai maksimum sebesar 0,0291 pada variabel penyerapan anggaran setelah penerapan aplikasi e-MPA. Nilai mean pada variabel X2 juga memiliki kondisi yang sama yaitu sebelum penggunaan aplikasi e-mpa lebih besar dibandingkan setelah implementasi aplikasi e-mpa. 
Tabel 2 Test Statistics ${ }^{\mathrm{a}}$

\begin{tabular}{lll}
\hline & $\begin{array}{l}\text { x1_after } \\
\text { x1_before }\end{array}$ & x2_after - \\
\hline $\mathrm{Z}$ & $-5,393^{\mathrm{b}}$ & $-1,672^{\mathrm{b}}$ \\
$\begin{array}{l}\text { Asymp. Sig. (2- } \\
\text { tailed) }\end{array}$ &, 000 &, 094 \\
\hline
\end{tabular}

a. Wilcoxon Signed Ranks Test

b. Based on positive ranks.

Sumber: Output SPSS Versi 22.

Berdasarkan hasil output yang tersaji dalam Tabel tersebut Nilai Asymp.Sig masing-masing variabel adalah 0,000dan 0,094. Hipotesis 1 memiliki hasil dengan nilai signifikansi kurang dari 0,05 dengan tingkat kepercayaan 95\% danhipotesis 2 memiliki hasil dengan nilai signifikansi kurang dari 0,1 dengan tingkat kepercayaan 90\%. Dengan demikian, Hipotesis 1 dan hipotesis 2 diinterpretasikan bahwa kedua variabel tersebut terdapat beda rata-rata dari dua kelompok data.

\section{Pembahasan}

\section{Konsistensi Penyerapan Anggaran}

Berdasarkan hasil Uji Beda Wilcoxon untuk variabel konsistensi penyerapan anggaran, nilai Asymp Sig.-nya adalah 0,000 atau kurang dari nilai $\alpha$ 0,1 sehingga dapat disimpulkan bahwa hipotesis 1 didukung. Artinya, konsistensi penyerapan anggaran sebelum dan setelah e-MPA menunjukkan hasil yang berbeda. Dengan demikian, hasil statistik ini menunjukkan bahwa beda yang terjadi pada variabel konsistensi penyerapan anggaran sebelum dan setelah implementasi e-MPA adalah terjadi penurunan konsistensi dalam penyerapan anggaran. Adapun definisi konsistensi dalam penyerapan anggaran adalah kondisi pada saat adanya kesesuaian antara perencanaan target penyerapan anggaran dan realisasi pelaksanaan anggaran yang dilaporkan secara berkala setiap bulannya (PMK No. 249 Tahun 2011) yang mana seharusnya nilai realisasi pelaksanaan anggaran adalah bernilai $100 \%$ dari rencana anggaran. Hasil statistik juga menunjukkan bahwa nilai variabel konsistensi pada saat setelah e-MPA mengalami penurunan, sehingga penggunaan aplikasi e-MPA tidak mampu meningkatkan nilai konsistensi penyerapan anggaran. e-MPA merupakan aplikasi yang muncul dengan adanya regulasi yang digulirkan oleh Pemerintah dengan fungsi utama sebagai pengawasan sebagaimana public interest theory. Regulasi disusun untuk tujuan memaksimalkan kesejahteraan masyarakat. Wujud kesejahteraan tersebut dalam hal ini adalah dengan berjalannya program yang telah dibuat oleh Pemerintah. Serapan anggaran yang inkonsisten antara rencana dan realisasinya menunjukkan bahwa Pemerintah belum mampu memaksimalkan perannya dalam merealisasikan program kerja untuk meningkatkan kesejahteraan masyarakat. Berdasaran hasil statistik tersebut, aplikasi e-MPA belum mampu mendorong konsistensi antara rencana anggaran dan realisasi anggaran. Adanya penurunan konsitensi atau peningkatan dalam inkonsistensi serapan anggaran diindikasikan karena over load tugas operator keuangan yang disebabkan karena banyaknya jenis aplikasi pelaporan keuangan yang menuntut pelaporan yang tepat waktu dengan jenis aplikasi yang berbeda. Menurut Goodhue dan Thompson (1995) dalam task/technology fit theory disebutkan teknologi akan mampu mendukung tugas jika teknologi tersebut didukung dengan kemampuan individu dan dukungan lingkungan kerja yang sesuai. Dalam hal ini, operator keuangan diindikasikan kurang terdukung dalam hal kemampuan menggunakan teknologi akibat banyaknya aplikasi yang wajib digunakan untuk media pelaporan serta ada indikasi kurangnya dukungan dalam lingkungan manajemen, misalnya kurangnya tenaga operator agar tidak overload dalam menggunakan aplikasi pelaporan keuangan. Teori kontijensi yang disebutkan oleh Gordhon dan Miller (1976), Otlley (1980), dan Fischer (1998) juga menyebutkan bahwa sebuah sistem informasi akuntansi dan pengendalian seperti halnya pengawasan yang menjadi tujuan aplikasi e-MPA ini hanya akan berjalan dengan baik apabila didukung oleh lingkungan kerja, kemampuan sumber daya manusia, dan strategi yang digunakan agar mencapai tujuan walapun 
dihadapkan dengan kondisi yang berbeda. Temuan dalam penelitian ini menujukkan adanya perubahan kondisi pada sebelum dan setelah implementasi aplikasi e-MPA. Perubahan kondisi tersebut adalah adanya perubahan sistem pengendalian dalam bentuk pengawasan pelaksanaan anggaran yang semula tidak dilaporkan dengan sebuah aplikasi menjadi laporan dengan aplikasi yang memerlukan kesiapan sumber daya yang tepat untuk menjalankannya. Faktor lingkungan yang dihadapkan dengan pertambahan jenis aplikasi yang harus digunakan oleh operator menyebabkan perubahan lingkungan kerja bagi karyawan.

\section{Penyerapan Anggaran}

Berdasarkan hasil Uji Beda Wilcoxon untuk variabel penyerapan anggaran, nilai Asymp Sig.nya adalah 0,094 atau kurang dari nilai $\alpha$ 0,1 sehingga dapat disimpulkan bahwa hipotesis 2 didukung. Artinya, penyerapan anggaran sebelum dan setelah e-MPA menunjukkan hasil yang berbeda. Aplikasi e-MPA berfungsi sebagai alat penyediaan data dan informasi sebagai bahan penyusunan perencanaan, pelaksanaan, pemantauan, pengendalian dan evaluasi pelaksanaan program dan anggaran dalam rangka mewujudkan kinerja pelaksanaan program dan anggaran yang transparan, efisien, efektif dan akunTabel. Pada intinya, aplikasi e-MPA akan mendorong peningkatan penyerapan anggaran sehingga mendorong kinerja dalam bentuk realisasi program untuk kesejahteraan masyarakat.Aplikasi e-MPA juga merupakan perwujudan agency theory yang mana dengan penggunaan aplikasi e-MPA ini mendorong pertanggungjawaban pemerintah selaku agen kepada masyarakat selaku prinsipal. Namun, dalam penelitian ini hasil statistik menunjukkan bahwa serapan sebelum impementasi e-MPA cenderung lebih besar daripada setelah aplikasi e-MPA. Ada beberapa alasan yang mendasari temuan ini. Berdasarkan teori task/technology fit, Dishaw dan Strong (1999) menyebutkan ada faktor-faktor dan risiko-risiko dalam implementasi teknologi informasi dalam organsasi. Kegagalan teknologi informasi dalam suatu organisasi diantaranya tidak mampu mengubah suatu kondisi ke kondisi lain yang diharapkan. Turner, et al. (2008) menemukan bahwa keberhasilan suatu teknologi informasi untuk mendukung organisasi adalah harus memiliki terdapat goal congruence antara atasan dengan bawahan. Dengan demikian perbedaan persepsi, pemahaman, dan arah tujuan di masa depan akan menyebabkan perbedaan cara kerja terhadap penggunaan teknologi tersebut. Selain itu, kemampuan sumber daya manusia harus sesuai dengan desain tugas yang diberikan dengan menggunakan teknologi informasi. Demikian pula dengan konsep desain harus tepat sesuai tujuan penggunaannya (Turner, et al., 2008).

Selain itu, Turner, et al. (2008) juga menjelaskan bahwa lingkungan manajemen pengguna teknologi informasi dalam organisasi juga mempengaruhi keberhasilan organisasi. Gebauer, et al. (2006) menyebutkan kinerja dengan basis teknologi dipandang secara umum sebagai kesatuan kerja yang berdasarkan tujuan bersama dengan memberikan tugas individu. Pemberian tugas individu untuk mendukung pencapaian tujuan bersama biasanya dihadapkan dengan komunikasi, pemahaman pada guidelines, dukungan pemrosesan informasi. Dengan demikian, serapan anggaran setelah penggunaan e-MPA yang belum menunjukkan peningkatan dari sebelum penggunaan e-MPA merupakan indikasi adanya kemungkinan tidak adanya goal congruence yang disebabkan oleh pola komunikasi, dukungan informasi, dan pemahaman pada guidelines dari aplikasi e-MPA yang kurang maksimal.

Selain itu, aplikasi e-MPA difungsikan sebagai pengawas dalam hal realisasi anggaran, sehingga penilaian keberhasilan suatu Satker dalam realiasasi anggaran dengan aplikasi e-MPA kurang tepat. Namun, hal ini juga dapat menjadi sesuatu yang menarik untuk diteliti mengingat bahwa e-MPA merupakan salah satu aplikasi yang muncul akibat adanya regulasi dan ditujukan untuk memenuhi kewajiban agen terhadap prinsipal. Disamping itu, operator di dalam lingkungan Kementrian Agama dihadapkan dengan berbagai tugas dengan berbagai aplikasi yang mewajibkan untuk digunakan dan dilaporkan, sehingga ini menjadi indikasi kelebihan beban kerja dalam tugas sebagai operator keuangan.

Perbedaan serapan anggaran setelah penggunaan aplikasi e-MPA yang menunjukkan penurunan sebagaimana terjadi hal yang sama dengan variabel konsistensi serapan anggaran juga dapat dijelaskan dengan alasan yang sama menurut teori Kontijensi. Faktor perubahan lingkungan 
akibat penambahan jenis aplikasi baru, teknologi informasi yang baru, kesiapan sumber daya yang mengoperasikan menjadi tantangan tersendiri bagi organisasi untuk mencapai tujuan walaupun dihadapkan dengan metode pelaporan yang berbeda.

\section{E. SIMPULAN DAN SARAN Simpulan}

Penelitian ini bertujuan untuk mengetahui perbedaan capaian kinerja sebelum dan sesudah penggunaan aplikasi e-MPA. Mendeskripsikan secara obyektif capaian kinerja pelaksanaan anggaran pasca implementasi aplikasi e-MPA pada satker kementeriaan agama di seluruh provinsi Lampung, dengan harapan dapat memberikan bukti dan gambaran yang lebih nyata mengenai keberhasilan capaian kinerja pelaksanaan anggaran yang dilaporkan melalui aplikasi e-MPA.

Berdasarkan hasil analisis dan pembahasan dapat penelitian ini, disimpulkan bahwa hipotesis 1 didukung. Artinya, konsistensi penyerapan anggaran sebelum dan setelah e-MPA menunjukkan hasil yang berbeda. Hasil statistik ini menunjukkan bahwa beda yang terjadi pada variabel konsistensi penyerapan anggaran sebelum dan setelah implementasi e-MPA adalah terjadi penurunan konsistensi dalam penyerapan anggaran. Adapun definisi konsistensi dalam penyerapan anggaran adalah kondisi pada saat adanya kesesuaian antara perencanaan target penyerapan anggaran dan realisasi pelaksanaan anggaran yang dilaporkan secara berkala setiap bulannya (PMK No. 249 Tahun 2011) yang mana seharusnya nilai realisasi pelaksanaan anggaran adalah bernilai 100\% dari rencana anggaran.

Dari hasil uji hipotesis variabel penyerapan anggaran dapat disimpulkan bahwa hipotesis 2 didukung. Artinya, penyerapan anggaran sebelum dan setelah e-MPA menunjukkan hasil yang berbeda. Namun, dalam penelitian ini hasil statistik menunjukkan bahwa serapan sebelum implementasi e-MPA cenderung lebih besar daripada setelah aplikasi e-MPA. Dengan demikian, serapan anggaran setelah penggunaan e-MPA yang belum menunjukkan peningkatan dari sebelum penggunaan e-MPA merupakan indikasi adanya kemungkinan tidak adanya goal congruence yang disebabkan oleh pola komunikasi, dukungan informasi, dan pemahaman pada guidelines dari aplikasi e-MPA yang kurang maksimal. Hal ini sesuai dengan konsep teori Task/Technology Fit dan teori Kontijensi. Kedua teori tersebut juga menjelaskan bahwa suatu sistem informasi dan teknologi akan berhasil apabila didukung oleh lingkungan, kesiapan sumber daya manusia, dan ketepatan strategi yang digunakan oleh organisasi dalam penggunaan teknologi tersebut.

\section{REFERENSI}

Bappenas. 2011. Laporan Identifikasi Permasalahan Penyerapan Anggaran Tahun 2011 di Enam Kementerian Lembaga Dan Satuan Kerja Pemerintah Daerah di Dua Provinsi. Bappenas. Retrieved from http://www.bappenas.go.id/files/ekps/2011/5. Diakses pada 19 September 2016. Pukul 15:29 WIB

Chang, Liu. 2012. Impact of E- government on the Government Performance Management. International Conference on Education Technology and Computer

Chua, A.dan Lam, W. 2005. Why KM projects fail: A multi-case analysis. Journal of Knowledge Management, 9(3): 6-17

Dishaw, M. T., \& Strong, D. M. 1999. Extending the technology acceptance model with tasktechnology fit constructs. Information \& Management, 36: 9-21

Fisher, G Joseph. 1998. Contingency Theory, Management Control System and Firm Outcomes: Past Results and Future Directions, Behavioural Research in Accounting Vol. 10.

Gea, A.A. 2006. Integritas Diri: Keungggulan Pribadi Tangguh. Character Building Journal, 3 (1): 1626

Gebauer, Judith; Shaw, Michael J.; dan Michele L. Gribbins. 2006. Task-Technology Fit for Mobile 
Information Systems. Working paper.

Ghozali, Imam. 2005. Aplikasi Analisis Multivariate dengan program SPSS, Badan Penerbit Universitas Diponegoro, Semarang

Goodhue, Dale L., \&Thompson, Ronald, L. 1995. Task-Technology Fit and Individual Performance. MIS Quarterly, June: 6-15.

Gordon, L.A., \& Miller, (1976). A Contingency Framework for the Design of Accounting Information System. Accounting, Organization and Society: 59- 69

Group Meta, SearchCIO.com. 2005. Executive Guide: IT Governance. Diakses pada 11 Juli 2008 dari http://www.kpmg.ca/en/services/advisory/err/inforiskmgmt.html

Gujarati, D.N. 2005. Basic Econometrics. 5th Ed. McGraw-Hill. New York

Jensen, M., \& Meckling, O.1976. Theory Of The Firm: Managerial Behavior, Agency Cost And Ownership Structure. Jurnal of Financial Economics 3 (4): 305-360.

Juliani, Dian., \& Sholihin, Mahfud. 2014. Pengaruh Faktor-Faktor Kontekstual Terhadap Persepsian Penyerapan Anggaran Terkait Pengadaan Barang/Jasa. 11 (2): 177 - 199.

Kareem, Mohanad Ali., \&Haseeni, Zeena Jabber. 2015. E-Government and Its Impact on Organizational Performance. International Journal of Management and Commerce Innovations 3 (1): $672-664$

Kenis, Izzettin. 1979. Effects of Budgetary Goal Characteristics on Managerial Attitudes and Performance. The Accounting Review 54 (4): 707-721

Kementrian Agama. 2016. Progres Pelaksanaan Anggaran Kementrian Agama Tahun 2016. Presentasi Paparan Sekeretaris Jenderal Kementrian Agama.

Kementrian Agama Provinsi Lampung. 2015. Rencana Strategis (Renstra) Kanwil Kementrian Agama Provinsi Lampung Tahun 2015-2019. Diakses melalui www.lampung.kemenag.go.id

Kemetrian Agama Provinsi Lampung. 2016. Laporan Kinerja Kemetrian Agama Provinsi Lampung. Diakses melalui www.lampung.kemenag.go.id

Kuncoro, E.D (2013), Analisis Penyerapan Anggaran Pasca AplikasiSIPPPada Satker PelaksanaanJalanNasionalWil.I Dinas PUprov.Kaltim. e-Jurnal.adbisnis.fisip-unmul.ac.id 1(4): 364-373

Kurniadi, Denny. 2015. Pengembangan Sistem Informasi Rencana Kerja Dan Anggaran Pada Dinas Pendidikan Kabupaten/Kota Berbasis Web. Jurnal Teknologi Informasi dan Pendidikan.8 (1):

Lembaga Administrasi Negara. 2000. Akuntabilitas dan Good Governance (Modul 1 dari 5). Jakarta.

Mahsun, M. 2006. Pengukuran Kinerja Sektor Publik. Penerbit BPFE. Yogyakarta.

Mardiasmo. 2002. Akuntansi Sektor Publik. Penerbit Andi. Yogyakarta.

Media Indonesia. 2012, Januari 31. e-MPA Kiat Pantau Serapan Anggaran. Ekonomi MI

Otlley, David. . T. 1980. The contijency theory of management. Accounting, Organization, and Society 5(4): 413-428

Parker, Wayne C. 1993. Performance Measurement In The Public Sector. State Of Utah.

Peraturan Menteri Agama Nomor 47 Tahun 2014 tentang Monitoring Pelaksanaan Anggaran Secara Elektronik.

Peraturan Menteri Keuangan Nomor 249 Tahun 2011 Tentang Pengukuran dan Evaluasi Kinerja atas Pelaksanaan Rencana Kerja dan Anggaran Kementerian Negara dan Lembaga. 
Pasoloran, Oktavianus, Pengaruh Perceived Enviroment Uncertainty (PEU) terhadap hubungan antara Karakteristik Sasaran Penganggaran dengan Kinerja Manajerial (Studi Empiris pada Kawasan Industri Makasar), Simposium Nasional Akuntansi 5, Semarang, tanggal 5 - 6 September 2002, hal. $756-774$.

Prastowo, Nono Agung. 2014. Penerapan dan Implementasi Anggaran Berbasis Kinerja. Jejaring Administrasi Publik. VI (1): 520-528

Putra., R B., \& Sensus., D., I. 2008. Rancangan Tata Kelola TI Untuk Institusi Pemerintah Studi Kasus Bappenas. Jurnal Sistem Informasi MTI-UI. 4 (1)

Ratmono, Dwi., \&Suryani, Rita. 2016. Anteseden Dan Konsekuensi Keberhasilan Implementasi Performance-Based. Jurnal Akuntansi \& Auditing Indonesia, 20 (1):

Ross, Jeanne., \& Weill, Peter. 2004. Recipe For Good Governance, CIO Magazine, 15 June 2004, 17, (17).

Rozai , M. A., \& Subagiyo, L. 2015. Optimalisasi Penyerapan Anggaran Dalam Rangka Pencapaian Kinerja Organisasi (Studi Kasus Pada Inspektorat Kabupaten Boyolali). Jurnal Manajemen Sumberdaya Manusia. Vol. 9 No. 1 Juni 2015: 72 - 89

Scoot, W.R. 2009. Financial Accounting Theory. Fifth Edition. Canada Prentice Hall.

Simons, R. 2000. Performance Measurement And Control Systems For Implementing Strategy. Prentice Hall

Sofyani, Hafiez., \& Akbar, Rusdi. 2013.Hubungan Faktor Internal Institusi Dan Implementasi Sistem Akuntabilitas Kinerja Instansi Pemerintah (Sakip) Di Pemerintah Daerah. Jurnal Akuntansi dan Keuangan Indonesia. Desember 2013, Vol. 10, No. 2, hal 184 - 205

Stanimirovic, Dalibor., \& Mirko Vintar. 2013. A Critical Insight into the Evaluation of e- Government Policies: Reflections on the Concept of Public Interest. International Journal on Advances in Life Sciences. 5 (1,2).P. 52-64

Sugiarto, Agus., \& Mutiari, Dyah. 2016. Konsistensi Perencanaan Pembangunan Daerah Dengan Anggaran Daerah. Prosiding Interdisciplinery Postgraduate Student Conference $3^{\text {rd }}$ (PPs UMY).

Sugiyono, 2013. Metode Penelitian Kuantitatif, Kualitatif Dan Kombinasi (Mixed Methods). Bandung

Turner, Jason M.; Biros, David P.; dan Michael W. Moseley. 2008. "KMS-Fit": a case-based exploration of task/technology fit in an applied knowledge management context. Knowledge Management \& E-Learning: An International Journal. 1(2): 120-138

Whittaker, James B. 2000. The Government Performnace Results Act of 1993.

Zakaria. 2011. Key performance indikators (KPIs) in public sector: a study in Malaysia. 